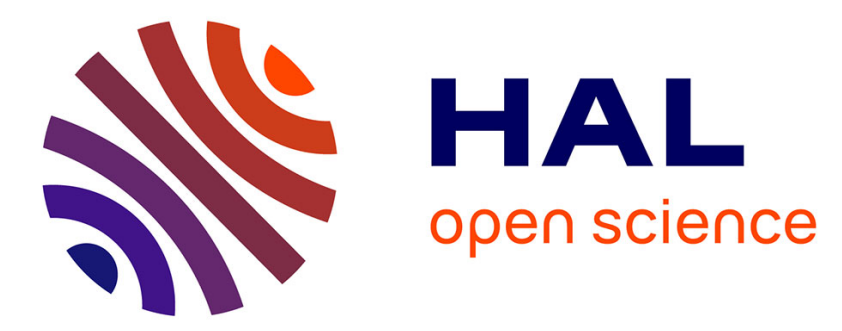

\title{
Tumor necrosis factor receptor 1-associated periodic syndrome without fever: cytokine profile before and during etanercept treatment
}

\author{
H. Morbach, P. Richl, S. Stojanov, P. Lohse, Hermann J. Girschick
}

\section{- To cite this version:}

H. Morbach, P. Richl, S. Stojanov, P. Lohse, Hermann J. Girschick. Tumor necrosis factor receptor 1associated periodic syndrome without fever: cytokine profile before and during etanercept treatment. Rheumatology International, 2009, 30 (2), pp.207-212. 10.1007/s00296-009-0937-0 . hal-00568289

\section{HAL Id: hal-00568289 \\ https://hal.science/hal-00568289}

Submitted on 23 Feb 2011

HAL is a multi-disciplinary open access archive for the deposit and dissemination of scientific research documents, whether they are published or not. The documents may come from teaching and research institutions in France or abroad, or from public or private research centers.
L'archive ouverte pluridisciplinaire $\mathbf{H A L}$, est destinée au dépôt et à la diffusion de documents scientifiques de niveau recherche, publiés ou non, émanant des établissements d'enseignement et de recherche français ou étrangers, des laboratoires publics ou privés. 


\title{
Tumor necrosis factor receptor 1 -associated periodic syndrome
}

(TRAPS) without fever - cytokine profile before and during etanercept treatment

\author{
H. Morbach ${ }^{1}$, P. Richl ${ }^{1}$, S. Stojanov ${ }^{2}$, P. Lohse ${ }^{3}$, H. J. Girschick ${ }^{1}$ \\ ${ }^{1}$ Children's Hospital, University of Wuerzburg, Germany \\ Morbach h@kinderklinik.uni-wuerzburg.de \\ prichl@web.de \\ Hermann.Girschick@mail.uni-wuerzburg.de \\ ${ }^{2}$ Children's Hospital, University of Munich, Germany; \\ currently: Genetics and Genomics Branch, NIAMS, NIH, Bethesda, \\ USA \\ stojanos@mail.nih.gov \\ ${ }^{3}$ Department of Clinical Chemistry - Großhadern, University of Munich, \\ Germany \\ Peter.Lohse@med.uni-muenchen.de
}

Corresponding author:

Hermann Girschick, MD

University Professor of Pediatrics

Section of Pediatric Rheumatology and Osteology

Children's Hospital, University of Würzburg

Josef-Schneider-Str. 2

D-97080 Würzburg, Germany

Tel: 4993120127725

Fax: 4993120127720

Email: Hermann.Girschick@mail.uni-wuerzburg.de 


\section{Key words}

Periodic fever

Autoinflammatory disease

TRAPS

Etanercept therapy

Cytokines

Interleukins 


\section{Abstract}

Objective. Autoinflammatory syndromes are usually characterized by repeated attacks of fever, especially in children. The presentation of these diseases, however, varies between entities and between patients of a particular syndrome.

Subject. We report a 16-year-old female patient, who suffered from periodic erythema and myositis/fasciitis. She experienced at least 9 attacks of dermatitis and myositis, while no fever episodes were noted over a 3-year period. A delay of puberty with amenorrhea and a short stature were also present.

Results. Laboratory investigations consistently showed markedly increased inflammatory parameters (especially a high serum amyloid A) and dysproteinemia. Because the patient's mother complained about chronic and periodic abdominal pain with also persistently elevated inflammatory parameters, the differential diagnosis included hereditary disorders resulting in chronic inflammation. The diagnosis of an inherited tumor necrosis factor receptor (TNFR) 1-associated periodic syndrome (TRAPS) was confirmed by genetic analyses. Long-term anti-inflammatory treatment with etanercept resulted in a significant clinical improvement and reduction of the inflammatory parameters ESR, CRP, interleukin-6, TNF- $\alpha$, and soluble TNF- $\alpha$ receptor 1 , but not of interleukin-12.

Conclusion: Monitoring of the cytokine profile suggested partial effectiveness of etanercept in the treatment of TRAPS. Hereditary fever syndromes have to be considered in case of chronic unexplained inflammation even if fever is no presenting symptom. 


\section{Introduction}

Tumor necrosis factor receptor (TNFR) 1-associated periodic syndrome (TRAPS; OMIM 142680) is the most common autosomal dominantly inherited periodic fever syndrome (10). This disease group also includes the autosomal recessively and dominantly inherited familial Mediterranean fever (MIM 249100), the autosomal recessive hyperimmunoglobulinemia $D$ and periodic fever syndrome (MIM 260920), and the autosomal dominantly transmitted cryopyrin-associated periodic syndromes (CAPS; MIM191900, MIM120100, and MIM607115).

TRAPS is characterized by recurrent attacks of fever, abdominal pain, synovial inflammation, migratory rash, conjunctivitis, and unilateral periorbital edema with a duration of at least 5 days up to 4 weeks. The phenotypic presentation of affected patients, however, varies considerably. TRAPS is caused by mutations in the TNFRSF1A gene, which encodes the TNF receptor 1 (TNFR1). This transmembrane receptor contains four cystein-rich domains (CRDs) in the extracellular region and an intracellular death domain which can signal apoptosis via death domain proteins or activate transcription factor NF-kB and bring forth inflammation. Mutations described in association with TRAPS are mostly missense mutations, which may involve cysteine residues that are part of structurally important disulfide bonds (18).

How TNFR1 mutations lead to the inflammatory phenotype of TRAPS is still under investigation. One early explanation was the so-called shedding hypothesis (12). After activation of the receptor, the extracellular part is normally shed from the cell surface by metalloproteases. This soluble TNFR1 (sTNFR1) is able to effectively neutralize TNF- $\alpha$ in the plasma. Initial observations in TRAPS patients showed increased cell surface TNFR1 and decreased plasma levels of soluble TNFR1 (sTNFR1), which resulted in increased and prolonged TNF- $\alpha$ signaling and decreased blocking of circulating TNF- $\alpha$. However, with the number of TRAPS mutations increasing, further studies demonstrated that cleavage defects are not generally found in association with TRAPS mutations. Thus, the shedding hypothesis can't be the sole explanation for the pathogenesis of TRAPS. Recent findings strongly suggest additional signaling defects in TRAPS patients . In vitro experiments 
performed by Rebelo et al. (14) demonstrated that the mutant TNFR1 may aggregate and be retained in the cytoplasm, resulting in defective cell surface expression and ligand-independent signaling. In a similar study by Lobito et al. (11), mutant TNFR1s showed reduced surface expression which correlated with reduced apoptosis induction and NF- $\mathrm{kB}$ signaling. The structurally altered receptors failed to interact with the wild-type receptor and instead formed abnormal disulfide-linked self-aggregates which were retained intracellularly in the endoplasmatic reticulum (ER). These findings indicate that the inflammatory phenotype of TRAPS may be due to mutant receptor misfolding, and subsequent induction of cytokines like IL-1 $\beta$ due to an unfolded protein response.

Corticosteroids are generally effective in reducing inflammation in TRAPS, but high doses are often required. When the genetic basis of TRAPS was identified, great hope was placed on an anti-TNF- $\alpha$ therapy, with etanercept being the most commonly used anti-TNF- $\alpha$ agent in TRAPS today. Various publications about the effect of etanercept are available, but results are mixed. It seems that etanercept is of use in replacing or reducing steroids, but the response can also be only a partial one or even be absent in some cases. The long-term benefit and potential adverse effects of etanercept in TRAPS are unknown. Recently, successful IL-1 blockade has been described in patients refractory to an etanercept therapy (6) (15). 


\section{Clinical Report}

The 16-year-old girl initially presented with the incidental finding of a high CRP of $7.6 \mathrm{mg} / \mathrm{dl}$ and of an increased ESR of $93 \mathrm{~mm} /$ hour. She mentioned recurrent attacks of localized pain and redness of her extremities at varying locations since she was 13 (Figure 1). These symptoms were mostly affecting her thighs or upper arms and were sometimes associated with mild swelling of the joints, lasting for several days up to one week. Up to 10 episodes per year were noted. Fever had never occurred during these episodes. She also reported occasional conjunctivitis and swelling of one of her eyelids. Her skin showed a slightly greyish complexion. She didn't have her menarche yet and her pubertal development was delayed (Tanner stage BII, PHI). She was of short stature (20th percentile) and her weight had been persistently low (2 kg below 3rd percentile). Microcytic anemia was noted (Hb $10.4 \mathrm{~g} / \mathrm{dl}, \mathrm{MCH} 20.3$

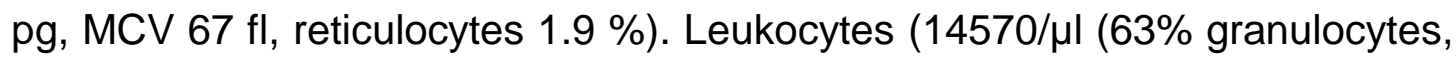
no blasts) and platelets $(732000 / \mu \mathrm{l})$ were elevated. Inflammatory parameters were significantly increased: ESR $93 \mathrm{~mm} / \mathrm{h}, \mathrm{CRP} 7.6 \mathrm{mg} / \mathrm{dl}$, serum amyloid A (SAA) $736 \mathrm{mg} / \mathrm{dl}$ (normal range $<10 \mathrm{mg} / \mathrm{d}$ ), serum $\mathrm{lgG}$ (polyclonal rise to $2410 \mathrm{mg} / \mathrm{dl}$, normal range $770-1510 \mathrm{mg} / \mathrm{dl}$ ). Iron metabolism showed a serum iron of $18 \mu \mathrm{g} / \mathrm{dl}$ and a ferritine of $70 \mu \mathrm{g} / \mathrm{l}$ (normal range: 9.3-59 $\mu \mathrm{g} / \mathrm{l}$ ). Further analyses including $\lg \mathrm{D}, \lg \mathrm{A}, \lg \mathrm{M}$, thyroid and growth hormones as well as autoimmune antibodies (ANA, ENA, ANCA, dsDNA) and a tuberculin skin test were unremarkable. A bone marrow examination showed unspecific inflammatory changes. The constellation of increased acute phase reactants associated with recurrent episodes of localized myositis supported the diagnosis of an autoinflammatory syndrome. Subsequent evaluation of the family's history revealed that the patient's mother had suffered from episodes of severe stomach pain related to cholecystitis associated with a high ESR of $85 \mathrm{~mm} /$ hour. Therefore - despite the fact that no fever was ever present further diagnostic analyses of our patient were initiated, targeting hereditary fever syndromes. DNA sequence analysis of exons $2,3,4$, and 6 of the TNFRSF1A gene (16), encoding the 55-kDa receptor for TNF- $\alpha$, revealed a $\mathrm{T} \rightarrow \mathrm{C}$ nucleotide substitution in exon 2 which leads to the replacement of 
tyrosine (TAT) by histidine (CAT) at amino acid position 20 (Y2OH). Genetic analysis of the mother revealed the presence of the identical mutation.

After the diagnosis of TRAPS was made, treatment with etanercept, a dimeric molecule joining the $75-\mathrm{kDa}$ TNF-alpha receptor with the Fc portion of a human $\lg \mathrm{G} 1$ antibody, was initiated $(0.4 \mathrm{mg} / \mathrm{kg}$ subcutaneously twice a week). The patient responded promptly with an improved physical condition. In the following months, a gain of weight and a rapid development of puberty (onset of menstrual bleeding, rapidly advancing breast and pubic hair growth) were noted. Episodes of focal myositis and erythema decreased in intensity and in frequency to about one to two per year. Attacks responded promptly to an additional naproxen or oral glucocorticoid therapy $(0.2 \mathrm{mg} / \mathrm{kg}$ prednisone for two days). ESR, CRP, and serum amyloid A were within the normal range, except during attacks (Figure 2a). Anemia improved to $11.5 \mathrm{~g} / \mathrm{dl}$. IgG titers remained elevated (1600 - $2140 \mathrm{mg} / \mathrm{dl})$.

The peripheral blood cytokine pattern of the TRAPS patient before and during TNF- $\alpha$ blockade with etanercept was analyzed by ELISA technique (Bender Med Systems, Vienna, Austria). Serum concentrations of IL-6, IL12p70, TNF- $\alpha$, and the sTNFR1 were determined during a 2-year period. IL-6, TNF-alpha, and sTNFR1 serum levels correlated well with markers of inflammation (ESR, CRP) (Figures 2b, c, d) as well as with clinical symptoms. IL-12, in contrast, remained elevated. After etanercept treatment, IL-6 serum levels decreased, whereas IL-12 concentrations increased (Figure 2e).

During 5 years of further follow-up, a streptococcal skin infection of the face and a one-sided superficial keratitis were noted as potentially therapyassociated side effects. Up to this point, fever associated with a flare has never occurred. Also, no clinical signs of amyloidosis have been found yet. 


\section{Discussion}

TRAPS usually presents before the age of 20 years with prolonged febrile episodes of at least 7 days up to several weeks (9). In our patient, however, fever was never present, thus challenging the diagnosis of a recurrent fever syndrome.

The $\mathrm{Y} 20 \mathrm{H}$ amino acid substitution detected in our patient has been described so far in two other patients and one asymptomatic carrier, thus suggesting a variable penetrance of this mutation (2). Disease onset (13 years of age) and duration of attacks (several days) in our patient corresponded to some extent with the data in the literature which described an average age of onset of 14 years and a fever duration of 2-4 days. Interestingly, a different amino acid substitution at the same position (Y20D) was reported to be associated with a very early disease onset at 1 year of age, prolonged febrile episodes, and severe abdominal pain, but no myositis and accompanying erythema (17). Whether this is indicative of the phenotypic heterogeneity or due to the heterozygous presence of another proinflammatory mutation (MEFV E148Q) in that proband, remains to be elucidated.

Usually TRAPS responds to high doses of oral corticosteroids. However, considering the underlying pathophysiology, etanercept seems to be the treatment of choice. It is considered safe in children (8) and has been successfully applied to a series of TRAPS patients (4; 5). Long-term antiinflammatory treatment with etanercept resulted in a dramatic clinical improvement and in a reduction of inflammatory parameters, thereby demonstrating its efficacy. Amyloidosis is the most severe complication of the disease and seems to occur more commonly in patients with cysteine mutations (7) (9) (3). Our patient so far did not show any signs of amyloidosis. Whether this is due to the non-cysteine $\mathrm{Y} 20 \mathrm{H}$ mutation, the relative short disease course of less than 10 years, or the partially effective treatment with etanercept, which has been shown to slow down or even reverse organ manifestation of amyloidosis in TRAPS (4), can actually not be decided.

Nowlan et al. (12) studied systemic pro-inflammatory cytokine levels in TRAPS patients affected by the C33Y mutation with and without etanercept treatment. They found that IL-6 concentrations were significantly increased 
and correlated with CRP levels in some of the affected patients. IL-8 was elevated as well. Neither TNF- $\alpha$ nor IL-1 $\beta$ demonstrated a similar increase. Etanercept appeared to induce an increased plasma concentration of TNF- $\alpha$, potentially by increasing TNF- $\alpha$ stability. Overall, the cytokine profile of TRAPS patients differed from the generalized elevation of pro-inflammatory cytokines typically observed in autoimmune or infectious inflammatory diseases (13)..

In our patient, we found that TNF- $\alpha$, TNFR1, and IL-6 were downregulated concordantly along with conventional markers of inflammation by etanercept. This resulted in a notable clinical improvement. IL-12 showed an opposite dynamic, as it increased under anti-TNF- $\alpha$ therapy. IL-12 is produced mainly by activated antigen presenting cells and has been shown to play a pivotal role in chronic inflammation (1).

We therefore hypothesize that cytokine production is disturbed in TRAPS patients receiving etanercept. Different proinflammatory cytokines seem to be differentially regulated during states of high and low amounts of free TNF- $\alpha$ molecules.

\section{Conclusion}

Especially in children, the presence of fever is an important clinical feature to establish the diagnosis of TRAPS. However, fever may not be present in every patient. Etanercept significantly improves the clinical status, although different proinflammatory cytokines seem to react differently once TNFblocking therapy is instituted. 


\section{Figure legends}

Figure 1: Dermatitis and myositis of the thigh of the 16-year-old TRAPS patient during a flare.

Localized pain, erythema, and soft tissue induration of the right thigh were noted during inflammatory attacks. These localized symptoms sometimes migrated on the affected extremity. Lesions in proximity to joints were associated with mild joint swelling and effusions and lasted for several days up to one week.

Figure 2: Inflammatory parameters during the course of the disease of the 16-year-old TRAPS patient.

Serial measurements of ESR, CRP, and serum amyloid A concentrations over a period of 22 months are shown (figure 2a). Etanercept treatment was started at the $3^{\text {rd }}$ time point shown (13.10.03), when a typical attack just had become clinically evident. Figure $2 \mathrm{~b}$ shows the measurement of TNF- $\alpha$, figure $2 \mathrm{c}$ of the soluble $60 \mathrm{kd}$ subunit of the TNF receptor 1 , figure $2 \mathrm{~d}$ of IL-6, and figure $2 \mathrm{e}$ of IL-12p70 in the patient's serum by using the ELISA technique.

Please note the subsequent and non-linear time points of the figures. 


\section{References}

1. Blanco P, Palucka AK, Pascual V and Banchereau J (2008) Dendritic cells and cytokines in human inflammatory and autoimmune diseases. Cytokine Growth Factor Rev 19: 41-52.

2. Dode C, Andre M, Bienvenu T, Hausfater P, Pecheux C, Bienvenu J, Lecron JC, Reinert P, Cattan D, Piette JC, Szajnert MF, Delpech M and Grateau G (2002) The enlarging clinical, genetic, and population spectrum of tumor necrosis factor receptor-associated periodic syndrome. Arthritis Rheum 46: $2181-8$.

3. Dode C, Cuisset L, Delpech M and Grateau G (2003) TNFRSF1Aassociated periodic syndrome (TRAPS), Muckle-Wells syndrome (MWS) and renal amyloidosis. J Nephrol 16: 435-7.

4. Drewe E, Huggins ML, Morgan AG, Cassidy MJ and Powell RJ (2004) Treatment of renal amyloidosis with etanercept in tumour necrosis factor receptor-associated periodic syndrome. Rheumatology (Oxford) 43: 1405-8.

5. Drewe E, McDermott EM, Powell PT, Isaacs JD and Powell RJ (2003) Prospective study of anti-tumour necrosis factor receptor superfamily $1 \mathrm{~B}$ fusion protein, and case study of anti-tumour necrosis factor receptor superfamily $1 \mathrm{~A}$ fusion protein, in tumour necrosis factor receptor associated periodic syndrome (TRAPS): clinical and laboratory findings in a series of seven patients. Rheumatology (Oxford) 42: 235-9.

6. Gattorno M, Pelagatti MA, Meini A, Obici L, Barcellona R, Federici S, Buoncompagni A, Plebani A, Merlini G and Martini A (2008) Persistent efficacy of anakinra in patients with tumor necrosis factor receptor-associated periodic syndrome. Arthritis Rheum 58: 1516-20.

7. Grateau G, Jeru I, Rouaghe S, Cazeneuve C, Ravet N, Duquesnoy P, Cuisset L, Dode C, Delpech M and Amselem S (2005) Amyloidosis and autoinflammatory syndromes. Curr Drug Targets Inflamm Allergy 4: 57-65.

8. Horneff G, Schmeling H, Biedermann T, Foeldvari I, Ganser G, Girschick HJ, Hospach T, Huppertz HI, Keitzer R, Kuster RM, Michels H, Moebius D, Rogalski B and Thon A (2004) The German etanercept registry for treatment of juvenile idiopathic arthritis. Ann Rheum Dis 63: 1638-44.

9. Hull KM, Drewe E, Aksentijevich I, Singh HK, Wong K, McDermott EM, Dean J, Powell RJ and Kastner DL (2002) The TNF receptor-associated periodic syndrome (TRAPS): emerging concepts of an autoinflammatory disorder. Medicine (Baltimore) 81: 349-68.

10. Hull KM, Shoham N, Chae JJ, Aksentijevich I and Kastner DL (2003) The expanding spectrum of systemic autoinflammatory disorders and their rheumatic manifestations. Curr Opin Rheumatol 15: 61-9. 
11. Lobito AA, Kimberley FC, Muppidi JR, Komarow H, Jackson AJ, Hull KM, Kastner DL, Screaton GR and Siegel RM (2006) Abnormal disulfide-linked oligomerization results in ER retention and altered signaling by TNFR1 mutants in TNFR1-associated periodic fever syndrome (TRAPS). Blood 108: 1320-7.

12. McDermott MF, Aksentijevich I, Galon J, McDermott EM, Ogunkolade BW, Centola M, Mansfield E, Gadina M, Karenko L, Pettersson T, McCarthy J, Frucht DM, Aringer M, Torosyan Y, Teppo AM, Wilson M, Karaarslan HM, Wan Y, Todd I, Wood G, Schlimgen R, Kumarajeewa TR, Cooper SM, Vella JP, Amos CI, Mulley J, Quane KA, Molloy MG, Ranki A, Powell RJ, Hitman GA, O'Shea JJ and Kastner DL (1999) Germline mutations in the extracellular domains of the $55 \mathrm{kDa}$ TNF receptor, TNFR1, define a family of dominantly inherited autoinflammatory syndromes. Cell 97: 133-44.

13. Nowlan ML, Drewe E, Bulsara H, Esposito N, Robins RA, Tighe PJ, Powell RJ and Todd I (2006) Systemic cytokine levels and the effects of etanercept in TNF receptor-associated periodic syndrome (TRAPS) involving a C33Y mutation in TNFRSF1A. Rheumatology (Oxford) 45: 31-7.

14. Rebelo SL, Bainbridge SE, Amel-Kashipaz MR, Radford PM, Powell RJ, Todd I and Tighe PJ (2006) Modeling of tumor necrosis factor receptor superfamily $1 \mathrm{~A}$ mutants associated with tumor necrosis factor receptorassociated periodic syndrome indicates misfolding consistent with abnormal function. Arthritis Rheum 54: 2674-87.

15. Sacre K, Brihaye B, Lidove O, Papo T, Pocidalo MA, Cuisset $L$ and Dode C (2008) Dramatic improvement following interleukin 1 beta blockade in tumor necrosis factor receptor-1-associated syndrome (TRAPS) resistant to antiTNF-alpha therapy. J Rheumatol 35: 357-8.

16. Stojanov S, Lohse P, Hoffmann F, Renner ED, Zellerer S, Kery A, Shin YS, Haas D, Hoffmann GF and Belohradsky BH (2004) Molecular analysis of the MVK and TNFRSF1A genes in patients with a clinical presentation typical of the hyperimmunoglobulinemia $D$ with periodic fever syndrome: a lowpenetrance TNFRSF1A variant in a heterozygous MVK carrier possibly influences the phenotype of hyperimmunoglobulinemia $D$ with periodic fever syndrome or vice versa. Arthritis Rheum 50: 1951-8.

17. Stojanov S, Lohse P, McDermott MF, Renner ED, Kery A, Mirakian R, Hammond LJ, Aganna E, Hoffmann F, Zellerer S and Belohradsky BH (2004) Periodic fever due to a novel TNFRSF1A mutation in a heterozygous Chinese carrier of MEFV E148Q. Rheumatology (Oxford) 43: 526-7.

18. Stojanov S and McDermott MF (2005) The tumour necrosis factor receptor-associated periodic syndrome: current concepts. Expert Rev Mol Med 7: 1-18. 

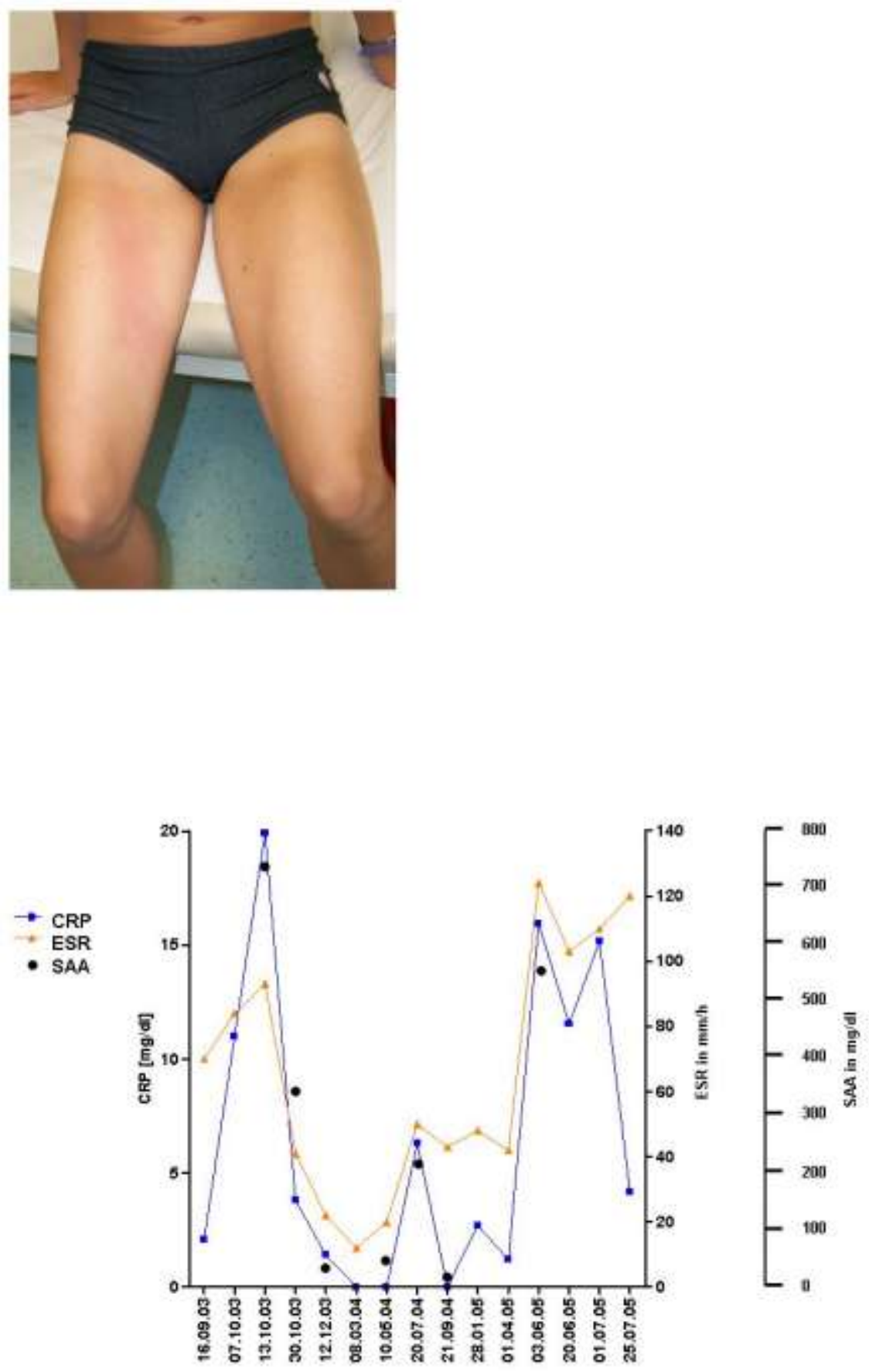

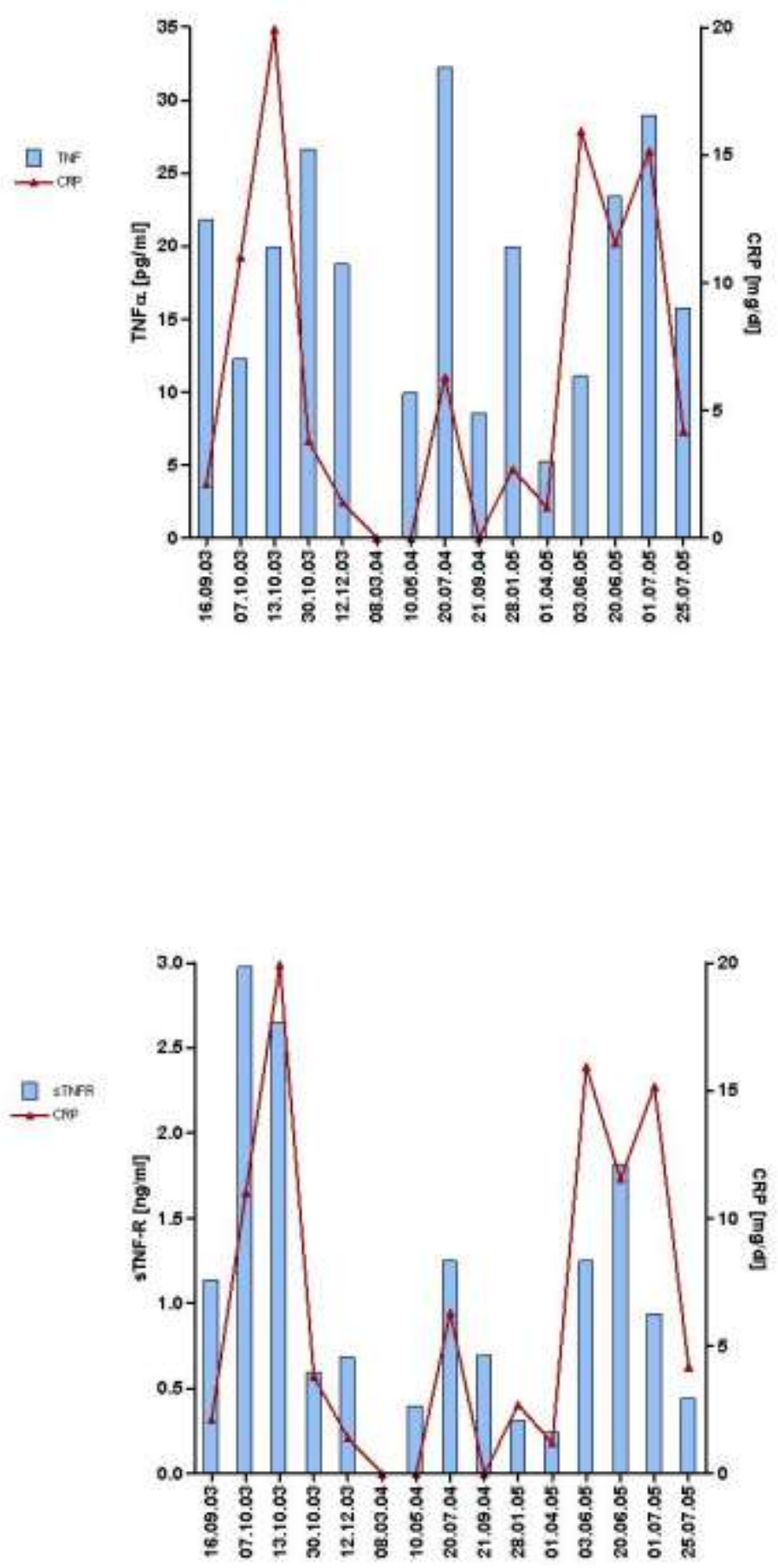

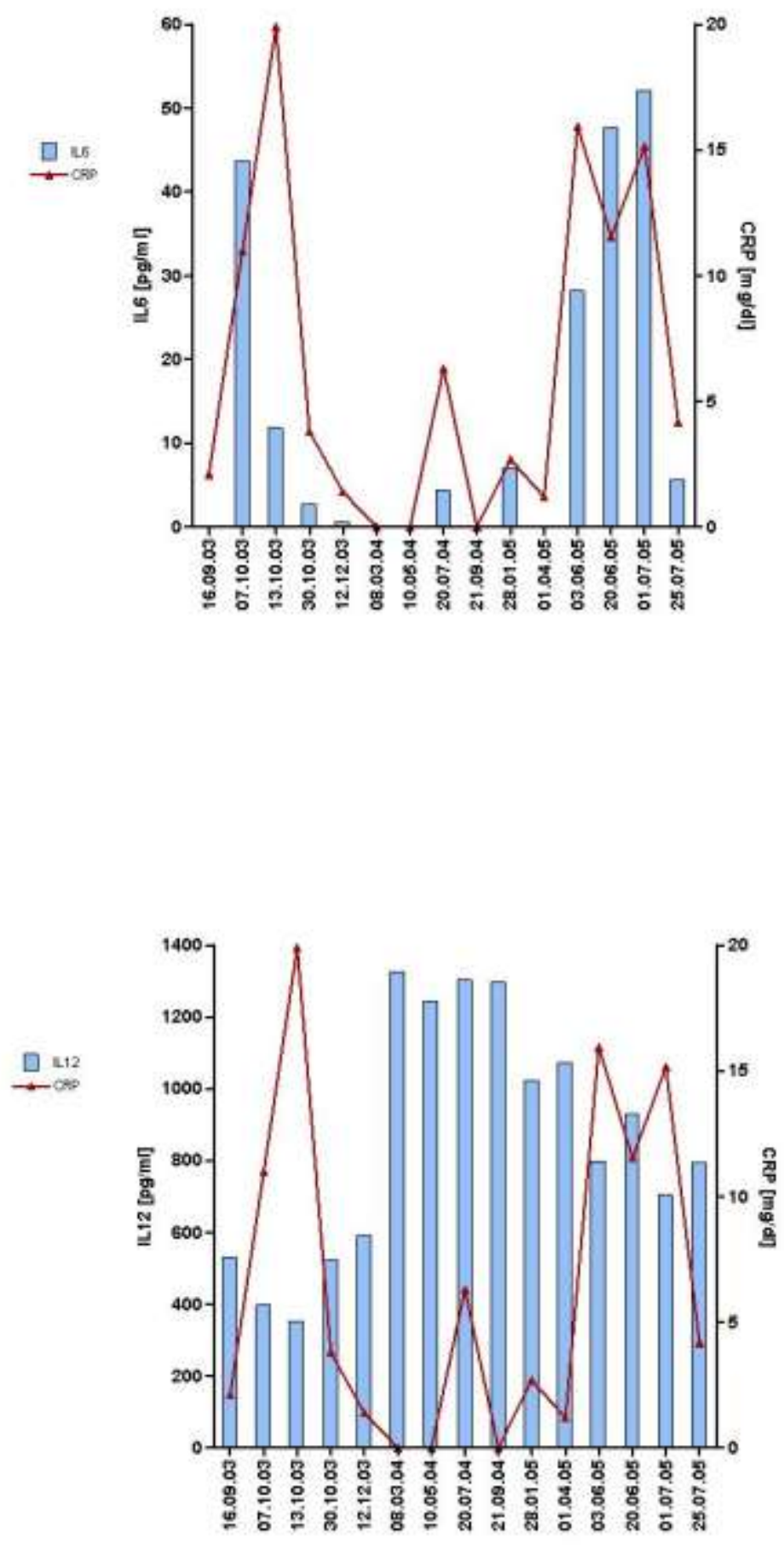